\title{
Florence Jullien. Histoire de Mār Abba, catholicos de l'Orient. Martyres de Mār Grigor, général en chef du roi Khusro Ier et de Mār Yazd-panāh, juge et gouverneur
}

Marie-Joseph Pierre

\section{(2) OpenEdition}

\section{Journals}

Édition électronique

URL : http://journals.openedition.org/abstractairanica/42755

DOI : $10.4000 /$ abstractairanica. 42755

ISBN : 1961-960X

ISSN : 1961-960X

Éditeur :

CNRS (UMR 7528 Mondes iraniens et indiens), Éditions de l'IFRI

\section{Référence électronique}

Marie-Joseph Pierre, « Florence Jullien. Histoire de Mār Abba, catholicos de l'Orient. Martyres de Mār Grigor, général en chef du roi Khusro ler et de Mār Yazd-panāh, juge et gouverneur », Abstracta Iranica [En ligne], Volume 37-38-39 | 2018, document 5, mis en ligne le 10 mars 2018, consulté le 26 septembre 2020. URL : http://journals.openedition.org/abstractairanica/42755 ; DOI : https://doi.org/ 10.4000/abstractairanica.42755

Ce document a été généré automatiquement le 26 septembre 2020.

Tous droits réservés 


\title{
Florence Jullien. Histoire de Mār Abba, catholicos de l'Orient. Martyres de Mār Grigor, général en chef du roi Khusro Ier et de Mār Yazd-panāh, juge et gouverneur
}

\author{
Marie-Joseph Pierre
}

\section{RÉFÉRENCE}

Florence Jullien. Histoire de Mār Abba, catholicos de l'Orient. Martyres de Mār Grigor, général en chef du roi Khusro Ier et de Mār Yazd-panāh, juge et gouverneur, (Corpus Scriptorum Christianorum Orientalium 658-659, Scriptores Syri 254-255), Louvain : Peeters, 2015, 138 p. +157 p.

Cette édition critique et commentée du texte syriaque à partir des manuscrits de Londres, de Berlin et du Vatican, est accompagnée d'une introduction, d'une traduction en français pour la première fois proposée, et d'un commentaire. Trois textes sont ici présentés. D'abord l'histoire du catholicos Mār Abba, chef de l'Église syro-orientale de 540 à 552 , qui fut sans doute l'un de ses plus illustres représentants, réunificateur de l'Église d'Orient après un schisme de près de vingt-cinq ans, canoniste, exégète, restaurateur de la discipline ecclésiastique qui avait été affaiblie depuis l'action de Barșauma en 484, controversiste réputé avec les zoroastriens et les chrétiens syroorthodoxes, médiateur de paix pour les communautés chrétiennes. Avec l'histoire du général en chef des armées perses Grigor Pirān-Gušnasp, et celle du juge Yazd-panāh, ce recueil nous introduit dans l'empire sassanide du règne de Khusro $\mathrm{I}^{\mathrm{er}}$ (531-579) qui fut l'une des périodes les plus brillantes de la Perse sassanide, marquée aussi par des persécutions sporadiques à l'encontre des chrétiens d'origine zoroastrienne. Ces textes, mis par écrit par des contemporains des événements, sont les seules hagiographies 
syro-orientales de cette époque à nous être parvenues en syriaque, et ils présentent une remarquable qualité d'informations sur le paysage socio-religieux et politique de l'Orient au $\mathrm{VI}^{\mathrm{e}}$ siècle. Cette édition princeps est désormais indispensable.

\section{AUTEURS}

\section{MARIE-JOSEPH PIERRE}

Directrice d'Études honoraire, EPHE 